\title{
The Attempted Repeal of the Quebec Act: The State of the Parliamentary \\ Opposition in 1775
}

\author{
Robin E. Close
}

ABSTRACT: The Artempted Repeal of the Quebec Act on 17 and 18 May 1775 is a subject which has, as of yet, not attracted Canadian or British Imperial historians working on eighteenth century Quebec. An examination of the repeal attempr made by Lord Camden and Sir George Savile in borh Houses of Parliament in 1775 reveals that the American Crisis led the Opposition to pursue a policy of conciliation with the American colonies. The attempred repeal of the Quebec Act was one way the Opposition hoped to head off the threat of imminent war. This study contributes to a fuller picture of the Imperial context in which decisions were made with regards to Canada during the rising American crisis.

On 17 May 1775, Lord Camden, ' former Lord Chancellor and now an active opponent to the ministry of Lord North on American issues, presented to the House of Lords a Petition of bis Majesty's loyal and dutiful subjects settled in the province of Quebec. In his speech to the Lords, he raised three issues arising from the petition: "the extension of the limits of Quebec, the establishment of popery there, and the civil despotism in which the inhabitants of that province are to be perpetually bound ..."2 Although he re-initiated the controversial discussion surrounding the legal and religious properties of the earlier Quebec Bill, Lord Camden's proposed Bill to repeal the Act for making more effectual provision for the government of the province of Quebec was rejected 88 to 13. The following day, Sir George Savile, ${ }^{3}$ representative for Yorkshire since 1759, made the same attempt to repeal the Quebec Act in the House of Commons. Again, the Bill of repeal was rejected 174 to 86 . It is apparent that both men thought that by echoing the contentious issues of 1774 , they could garner enough support to repeal the Act. The appeal to inflammatory issues of 1774 , however, failed to have the desired effect in May of 1775.

Because both attempts for the repeal of the Quebec Act failed so quickly and drew little debate within either of the two Houses, the attempted repeals of 1775 have not yet been considered by historians as significant events. Rather, ignoring the repeal attempts, Canadian historians tend to focus attention on the petitions sent by the British minority in Canada after the passing of the Quebec Bill as the beginning of the Anglo-French rivalry for the control of the government of 


\section{Past Imperfect}

Quebec. ${ }^{4}$ Other historians, such as R. Coupland ${ }^{5}$ and Philip Lawson, ${ }^{6}$ have treated the attempted repeals as an epilogue to the Quebec Act. Lawson's work does, however, offer some important insights for the purpose of this study on the attempted repeals of 1775 , with his argument that the focus by both Canadian and British historians on the Quebec Act has been misguided to date. According to Lawson, the Quebec Act should not be considered a coercive measure against America. ${ }^{7}$ Unlike other British historians, ${ }^{8}$ he further contends that opposition to the Quebec Act continued after the 22 June 1774 until the 1 May 1775 when the Act was to come into effect. "The Act entered popular radical mythology" and served as a platform for the more radical politicians during the 1774 general election. ${ }^{9}$ What he does not discuss, as it exceeds the scope of his study, is whether the controversial tone of the debates of 1774 was more than the temporary heared language used during elections and whether it persisted with high intensity as the American Crisis mounted towards war in 1775.

The general lack of interest amongst historians with regard to the attempted repeals of 1775 can perhaps be explained by the fact that the debates, themselves, fell short of the colourful discussion prior to the passing of the Quebec Bill. Yet, the fact that the debates in both Houses seemed listless in contrast to the more heated and controversial debate of 1774 is an observation which merits closer historical study. What would account for this listlessness at the very time when concern for the American Crisis was mounting, especially when the Quebec Act had been branded one of the Intolerable Acts by the Americans and their British sympathizers? Why was the Opposition unable to rally support against the provisions of the Quebec Act which had roused such passion only a year before? What does the failure of the repeal attempt in 1775 tell us about what was going on in British politics in these critical months?

An examination of the repeal attempt and its context, the rising American crisis, will show that the behaviour of the Opposition in 1775 is better explained by the exigencies of the American Crisis, than by any consistent policy of hostility to the Act's provisions. The Opposition was composed of different groups, each with its own position on the ministry's imperial policy. The largest group was led by Lord Rockingham. The Duke of Richmond, the Duke of Portland, and the Cavendish and Fox families also had their own followings while maintaining close ties with Rockingham. The Earl of Chatham and the Earl of Shelburne led the next largest number of supporters outside the Rockingham sphere of influence. In a provisional way we can note the following about the nature of the Opposition to the Quebec Act. First, the Opposition crossed party lines in 1775 as it had in $1774^{10}$; however, 
the Opposition was more characterized in 1775 by its common policy of conciliation with the Americans. Second, the repeal attempt appears to display two phases. Phase one, as defined by Lawson, consists of the period after the passing of the Quebec Bill on 22 June 1774 until the enactment dare of I May 1775." This phase includes both the immediate reacrion to the passage of the Bill, primarily pertaining to the religious clauses, and the use of the recent passage of the Bill in the ensuing election campaign to embarrass the Government. The second phase extends from 1 May 1775 to the vote on the attempted repeal on 17 May 1775. This phase is marked by Camden's introduction of the petition from the British minority in Quebec and his Bill for repeal.

What is remarkable about the second phase is the fact that the Opposition delayed moving a repeal attempt until sixteen days after the Bill's enactment instead of trying to prevent the Bill from taking effect in the first place. Why the delay? This question is even more puzzling when one considers that Camden had been in possession of the perition from Francis Maseres, the colony's representative in London, since February $1775 .{ }^{12}$ It appears that Camden intended to choose the riming of his move deliberately for what he considered maximum political advantage. In orher words, Camden might have miscalculated and let the more opportune earlier period pass. An assumption underlying this explanation is that Camden's strategy was directly related to issues of the Quebec Adit itself. If he were motivated primarily by his sentiments as an American sympathizer, however, his activities, including the timing of the repeal attempt, would be more directly related to the American crisis. If this could be said of Lord Camden, it seems reasonable to suppose that others shared his preoccupation with the threat of civil war.

One must consider, then, the context in which the attempted repeals were initiated. The month of January of 1775 proved to be a transition point in Parliament when it struggled with the notion of reconciliation on the one hand and the use of force on the other. On 19 January, the papers of General Gage were read in the Commons, revealing the American response to the Acts passed in the last session and suggesting war was ever more imminent. ${ }^{13}$ Almost as a response to the news from America, the Ministry designed more legislation and prepared to quell the disturbances in America by force. ${ }^{14}$ During the month of February, the Ministry and the King proposed the augmentation of the forces centred in America as well as a Bill for restraining the Trade and Commerce of the New England Colonies, which preceded the restraining bills for the Southern Colonies of March. ${ }^{15}$ The Parliamentary Opposirion, in turn, openly criticized the Ministry's policy as aggressive and one that could only lead to war. For the Opposition, it seemed that the 
news from Gage established the need for a plan of conciliation. On 20 January, the Earl of Chatham, ${ }^{16}$ introduced a motion for the withdrawal of troops in Boston, and, on 1 February, he brought forward his Provisional Act for settling the troubles in America, wherein he called for the repeal of all Acts pertaining to America since 1763, including the Quebec Act. However, on 20 February, Lord North, ${ }^{17}$ Prime Minister since 1770 , also introduced his Conciliatory Proposition to the Commons in respect to taxation. This attempt on behalf of Lord North was rejected by the Continental Congress which insisted that all legislation of 1774 be repealed. The resolutions for making peace with the Americans proposed by Edmund Burke, ${ }^{18}$ a prominent Rockingham supporter, followed North's Conciliatory Proposal on 22 March.

The Opposition found support amongst British merchants trading with the colonies. In these first few months of 1775 , there was a general increase in petitions from British merchants who desired appeasement with the Americans. On 23 January, the Merchants of London and Bristol sent a petition for the sake of trade with the colonies, which was again followed by a second petition of similar content on 26 January. On 2 February, the Opposition presented the Commons with a petition of the West India Planters respecting the American nonimportation agreements.

Despite these petitions and the concerns expressed by the Opposition for conciliation, the British Government continued down its path towards war. By May 1775, Parliament began to examine the army estimates and extraordinaries to finance British Forces should war break out in America or with Spain or France. ${ }^{19}$ Parliament's pre-occupation with financing war and the activities of American sympathizers provided the context in which the attempted repeals of May occurred. The debate of 15 May on the representation and remonstrance of the New York Assembly began with a petition from the General Assembly of New York presented to the Commons by Burke. In this debate, Lord North re-iterated Parliament's supremacy: "As to the Quebec duties, by which the province of New York was affected, as he did not pretend to be infallible, he confessed they were not laid exactly as they ought to be, he was willing to give satisfaction in that point immediately." ${ }^{20}$ Consequently, on the same day, the Commons ordered a Bill be brought in to explain and amend an Act to establish a Fund towards further defraying of the charges of the Administration of justice, and Support of the Civil Government, within the province of Quebec. Lord North, Bamber Gascoyne, and Grey Cooper were asked to prepare and bring in the same. ${ }^{21}$ The House of Commons Journals do not specify the initiator of the Bill, but it is more than likely that this Bill to amend the Quebec Revenue Act was initiated by the Opposition. The Bill had its second 
and third reading on 16 May and 18 May, was reported by the committee of the House on 17 May, and went before another committee on 19 May. Surprisingly, the Bill raised little opposition in either House and received Royal Assent on 26 May. ${ }^{22}$

The attempted repeal of the Quebec Act was initiated in the House of Lords following the 15 May Bill to amend and explain the Quebec Revenue Act. Any amendment to the Revenue Act, as a money bill, had to be initiated in the Commons.

The timing of the two proposals, one to improve the provisions of the Quebec Act and the other to repeal it, is at first sight surprising. If there had been a concerted strategy to repeal the Quebec Act, one would have expected a major battle in both Houses. Instead, in the Commons, the questioning of the financial aspects of the Quebec Act was rather mild and readily accepted by the Government. Clarification of the Revenue Act was needed. Lord North was "willing to give satisfaction to that point immediately."

Had the Opposition wanted to use the weakness of the Revenue Act to undermine the Quebec Act, this would have been an excellent strategy. Because the Revenue Act provided the financial basis for the government structure legislated by the Quebec Act, the latter would have been ineffectual without the financial provisions of the Revenue Act. By acceding to the amendment to the Revenue Act for improving the legislation, the Commons actually strengthened the Quebec Act, itself. Thus, Lord North's amendment to the Revenue Act was a rational response to a request for an improvement in the legislation. There is also no evidence to suggest that Lord Camden and his supporters had made any association between their efforts to repeal the Quebec Acr and the discussion in the Commons with regard to the Revenue Act. One might assume that if there had been any consideration taken, those who desired the repeal of the Quebec Act might have challenged the Revenue Act more rigorously. The proposal for the amendment of the Revenue Act, then, seems quite harmless with regard to any assault on the Quebec Act. One might suspect that the timing between the amendment and the attempted repeal was coincidental. Furthermore, one must conclude that opposition to the Quebec Act itself was centred in the House of Lords and it was there that the attempted repeal took place.

There was another explanation for the timing of Lord Camden's Bill for the repeal of the Quebec Act. A letter from the Duke of Richmond to Horace Walpole dated 9 May 1775 is the earliest indication that Lord Camden had set the date of repeal for $17 \mathrm{May} .{ }^{23}$ The letter also reveals that the Duke of Richmond was coming into town in order to be present 


\section{Past Imperfect}

for Lord Camden's motion about the Quebec Bill. Hence, the contents of the letter suggest that Camden was beginning to garner support amongst the Opposition. ${ }^{24}$ Certainly, there was a strong turnout in the House of Lords on 17 May $1775 .{ }^{25}$ In a letter that Camden sent to the Earl of Chatham on 12 February 1775, Lord Camden wrote the following:

I think it necessary to communicate to your Lordship, that I have received from $\mathrm{Mr}$. Maseres a petition from the Protestant settlers at Quebec, to repeal or amend that bill, and he has entrusted it to the management of the minority; without which liberty I did flatly refuse to receive it. He does not desire to bring it on yet this fortnight or three weeks; which gives full time to consider how it shall be introduced, and your Lordship's opinion will, I dare say, be attended to with the utmost respect by every body; for I am sure your Lordship's concurrence is of more worth to the cause than any other consideration. ${ }^{26}$

The timing of this letter comes both eleven days after Chatham's proposal for conciliation with America and amidst the Opposition's presentations of the petitions of merchants in America and Britain. Rockingham on 9 February wrote Chatham explaining the current situation of the petitions that he presented, "by which it will appear on record, that the merchants concerned in the American trade petitioned to be heard before any measure was taken, and that the West India planters and merchants desired to be heard immediately, and that they were refused. " ${ }^{27}$ Clearly there were many voices clamouring for attention at this critical time.

Lord Camden's date of acquiring the petition is uncertain. According to the Shortt and Doughty documents there were three petitions sent by the British citizens in Quebec: to the King, to the House of Lords, and to the House of Commons. Shortt and Doughty state that "these petitions were received by Mr. Maseres about the 12 or 13 of last January, 1775; and the first of them, that to the King's majesty, was delivered by him to the Earl of Dartmouth, his majesty's secretary of state for America, on the 18 of the same month; and those to the House of Lords and House of Commons were some time after delivered to the Lord Camden and Sir George Savile, who, approving the contents of them, undertook to present them to their respective houses of parliament. ${ }^{28}$ Camden, depending on Maseres's date of delivery, received the House of Lords' petition, then, anywhere between 12-13 of January and 1 February 1775. 
Clarification of the delay depends on the interpretacion of Camden's reference to "He does not desire to bring it on yet this fortnight or three weeks." Unfortunately for the historian examining this statement, it is not clear to whom Camden was referring when using the word "he" and there are no other letters to or from Camden that discuss the petition or the attempt for repeal. If Camden was implying that Maseres wished the delay, then one can assume that Maseres saw the moment in question inexpedient for dealing with issues concerning Quebec in light of Parliament's attention being solely focused on the American Crisis. If Camden was referring to a third person -- most likely the Earl of Dartmouth, secretary of state for the colonies, since he already had a copy of the Petition in his possession -- then the American Crisis must also be the cause of the delay in that the Ministry did not want to mix Quebec issues with the issues relative to America in this month of heated debate. Prior to Maseres' presentation to Dartmouth of the copy of the petition destined for the King, Dartmouth had been informed by Carleton that petitions would be sent as a reaction to the Quebec Act from the minority in Quebec. ${ }^{29}$

The last point of Lord Camden's letter to the Earl of Chatham which needs raising is that Maseres "entrusted [the perition] to the management of the minority." The "minority" might refer to the Chathamites. Chatham and his supporters, like Camden, Barré, and J. Townshend, ${ }^{30}$ had voted against the Quebec Act and had displayed a certain sympathy towards the British minority in Quebec in 1774. Secondly, the Chathamites were highly respected by American patriots who depended on their support and petitioning in London. The Rockinghamites were not as consistent in their opposition to the Quebec Bill, as Maseres discovered during the 1774 debates. Where Burke had appreciated the religious clauses, Chatham, as well as Camden, disagreed with the entire Bill. The Chathamites, then, were the most likely candidates for defending the cause of the British merchants of Quebec in Parliament. Maseres no doubt expected that Camden would involve Chatham, the great patrior, in the cause. But there is also another reason why Maseres's choice of Camden was appropriate. Camden had been an opponent of Lord Mansfield on several occasions in the past. ${ }^{31}$ It was believed by many contemporaries of Camden that Mansfield had been the true instigacor of the Intolerable Acts. ${ }^{32}$ Lord Edmond Fitzmaurice, in his biography of the Earl of Shelburne, even referred to Mansfield as "the real Prime Minister." 33

The debates of 17 and 18 May varied little in content from the debates of 1774 on the Quebec Bill. Both Lord Camden's and Sir George Savile's speeches for the repeal of the Quebec Act echoed the points raised by Chatham, Johnstone and Burke in 1774. On 17 June 
1774 Chatham had claimed that the Quebec Bill established a despotic government in the Province of Quebec, to which the Royal Proclamation of 1763 had promised the protection of the English Laws. ${ }^{34}$ Similarly, Governor Johnstone, on 6 June 1774 in the Commons, had accused the authors of the Bill of establishing a state of slavery, elevating the popish religion, deeming juries unnecessary, and implying "that French Laws and commercial regulations are preferable to English." 35 Edmund Burke had also shown some concern over the territory granted to the Province of Quebec at what seemed to be the expense of New York's potential for territorial expansion.

The attempted repeals of the 17 May and 18 May displayed the state of the Opposition before there was an effective coalition against government policy on North America. When one examines the debates themselves, it is apparent that in both Houses there was inconsistency of opinion on the policy. Each member who spoke out against the Act in the House of Lords had his own reason for repeal. Lord Camden argued for repeal on the basis that the Act was unlawful according to the British Constitution. ${ }^{36}$ The Duke of Richmond could very well have spoken on behalf of his Rockingham connection, in that he discussed the potential arbitrary powers of the Governor of Quebec without committing himself to the religious implications of Camden's speech. ${ }^{37}$ Shelburne, a frequent ally of Chatham's on American affairs, did not vote for the Bill of repeal but he scorned the Ministry for having suggested arming the French Canadians. ${ }^{38}$

The Commons displayed somewhat greater coherence within emerging opposition groups without, however, their coalescing into a uniform Opposition. Sir George Savile tended to be an independent country gentleman who, although he was often in consultation with Rockingham, had his own position on the Quebec Act. ${ }^{39}$ James Townshend and Colonel Isaac Barré represented the radical view associated with the Chathamite group. They argued that the Act was "unjust, impolitic, and unconstitutional." 40 According to Bernard Donoughue, Charles Fox would have voted within the Rockingham sphere of influence ${ }^{41}$ or, rather, according to Philip Lawson, he would have voted on the Bill of repeal's merit and not simply for the sake of upholding party ideology. ${ }^{42}$ Whether or not he voted for or against the Bill of repeal, Fox made known his disgust for the administration and its hypocritical reasons for devising the Act in the first place. ${ }^{43}$

If one considers the voting trends for the two Bills, the Quebec Act and the attempted repeal, one is led to believe that between 1774 and 1775 very few Peers or Commoners changed their stand on the Quebec Act. There seem to be three groups: those who remained consistent in their policy toward the Quebec Act, either for or against, ${ }^{44}$ and those 
who changed their policy, most likely because of the American Crisis. The second group, mostly comprised of Chathamites, led the attack on the legislation and was, evidently, the most outspoken group. What is harder to explain is the change of support of Lord Hillsborough, ${ }^{45}$ former secretary of state for the colonies, who had fought against the Quebec Bill in 1774 on the grounds that the new boundary set by the Bill would hamper Protestant settlement and ruin Indian trade, ${ }^{46}$ but did not vote for repeal in 1775 . In fact, he did not even speak during the repeal attempt.

The London Evening Post's record of the debate of 17 May reinforces the view that the Opposition attack should be interpreted in light of the American Crisis. Lord Camden is recorded as having said that "the Quebec Bill seemed to have been principally framed with a view of checking the ardor of the other American Colonies in their praise worthy struggles for liberty." 47 The Duke of Richmond's speech is described as an attack on the "wicked ministers" for "the deeds of darkness they had committed." The Postalso summarized the speech of the Honourable Thomas Lyttelton, an advocate of the British cause against the colonies, as amounting to an accusation against Lord Camden and the Duke of Richmond for asserting and supporting "rebellious measures in both Houses of Parliament." The interpretation of the London Evening Post was still representative of the radical views that had been published during the debate around the Quebec Bill in 1774.

The condition of the Opposition seemed to be disunited with respect to America in the early months of 1775 . Members acted according to party rather than as a uniform body opposing the government. According to Fitzmaurice, there were occasions when "the eloquence of Burke had vied with that of Chatham, the learning of Dunning with that of Camden, in denouncing the unconstitutional character of the proposals of the Government. . . . But there was neither real concert nor lasting union." 48 However, there were members who saw the need for a coherent policy between groups. By June 1775, Walpole insisted that the Opposition needed to be united in order to overturn the Cabal. "the most that can be said of the Opposition, is, that they are very dear to the Americans, who will not trust us, unless they see all their friends in power." 49 The show of leadership of the Duke of Grafton, Prime Minister until 1770 and Lord of the Privy Seal since $1771,{ }^{50}$ and his plan of action for conciliation with America "enabled the Opposition to act with greater vigour and union during the winter of 1775 than it had done for some time past." 51 Grafton shared similar views with Lord Shelburne in respect to America and described the joint effort: "the Opposition was most honourably engaged: and it was with the most 
hearty concurrence with the principal men who composed it, that I added my little aid: having fully opened our minds to each other, and found little difference in our opinions." 52

At the time of the attempted repeal of the Quebec Act, then, the Opposition was just beginning to harden its position on the Government's North American policy. From a variety of different perspectives, the Opposition was concluding that the Ministry's tough stand on America was dangerously wrong-headed. We have seen how the American crisis cast an enormous shadow over the business of Parliament in the Spring of 1775. Although to some degree incidental to the question of repeal, one aspect of the debate revealed an ominous new danger that made the refusal to conciliate the Americans very risky indeed - a new concern for potential hostilities with England's traditional enemies, France and Spain. North's apparent readiness to arm the Canadians as a force to subdue the American rebel $s^{53}$ at the very time that France and Spain seemed to be preparing for war against England would have been regarded as exceedingly dangerous. Lord Lyttelton, although he supported the Quebec Act and was engaged in chastising Camden for trying to open old wounds with his repeal attempt, made the connection between the pre-occupation with the American crisis and the danger of war in the European theatre:

your Legions have been sent across the Atlantic, to shake their Banners in Fields of Peace, and to compel those infatuated Men to Obedience who would have been better and more effectually bound by the Energy and Acts of Parliament; the Enemy, the common Enemy, has prepared a Force superior to any you have to oppose to her ... Spain, my Lords, Spain, panting for War and eager for Revenge. ${ }^{54}$

Lyttelton's speech focused attention on the military implications of the government's policy towards America, but at the expense of defusing the opposition in the Lords to the Quebec Act. That the threat in Europe was indeed becoming a factor in the Opposition's thinking at this time can be inferred from the fact that Colonel Barré concluded his speech to the Commons demanding repeal of the Quebec Act with a similar reference to Spanish armament. In the light of this new danger, risking hostilities in America seemed a foolhardy policy which would increasingly galvanize the Opposition. In May 1775, the Quebec Act did not constitute such an important irritant that the Opposition, undistracted by the apparently more pressing concern of an external war coinciding with an imminent civil war, was able to sustain a concerted attack against it. At the same time, without more cogent arguments 
than those offered by the Opposition, Government supporters were not about to be deflected from their conviction that the Quebec Act had at least temporarily solved administrative problems in one part of British North America, making Quebec one less colony to be concerned about in such dangerous times.

In the course of this study, many of the questions raised at the outset have received partial answer at least. Clearly more research is warranted before one can speak confidently of such matters as the timing and motives of Camden's repeal attempt. Closer examination of the election of 1774 and the residual attitudes concerning the Quebec Act in the period leading up to the repeal attempt of 1775 are called for. The fact that the old arguments of 1774 which had raised such passion at that time - for example the religious clause - were less apparent in May 1775 makes the repeal attempt an intriguing historical puzzle. 


\section{NOTES}

'Charles Prart, Earl of Camden, was Lord Chancellor until 1770. He lost his position after he had denounced the American import duties and the Middlesex election as illegal and arbirrary. Lord Camden has been called a "zealous Pittite". He was a school fellow of William Pitt and this association served Pratt well under the Chatham administration in 1757, giving him a seat in Parliament for Downton in Wiltshire, and, in 1766, when Chatham returned to power, giving him the title of Lord Chancellor. While Pratt was Chief Justice of Common Pleas in the 1760 s, he had discharged John Wilkes from imprisonment and pronounced the General Warrant of the secretary of state to be wholly illegal. See Edward Foss, The Judges of England (New York, 1966), 357-363.

2 "Debate in the Lords on Lord Camden's Bill to repeal the Quebec Government Act," in Parliamentary History of England, vol. 18, ed. W. Cobbett (London, 1813), 655

${ }^{3} \mathrm{Sir}$ George Savile had in the 1760 s supported the repeal of the Stamp Acr as a means of appeasing the Americans while maintaining the position that Parliament was supreme throughout the British Empire. By 1774, his views on the American Crisis had changed from the idea that the colonies were acting as "naughty children". On February 10, 1775, Savile went so far as to describe the American Resistance as a "justifiable rebellion". See Sir Lewis Namier and John Brooke, The History of Parliament: The House of Commons, vol. 3 (London, 1964), 408.

${ }^{4}$ See the French Canadian historians François-Xavier Garneau, Cours d'Histoire du Canada, vol. 1 (Quebec, 1919); Michel Brunet, French Canadians and Early British Rule (Otrawa, 1968); Thomas Chapais, Cours d'Histoire du Canada, vol. 1 (Quebec, 1919). See the English speaking Canadian historians A.L. Burr, The Old Province of Quebec (Toronto, 1968); Hilda Neatby, The Quebec Act: Protest and Policy (Scarborough, 1972).

${ }^{5}$ Sir Reginald Coupland, The Quebec Act: A Study in Statesmanship (Oxford, 1925), 135-137

${ }^{6}$ Philip Lawson, The Imperial Challenge: Quebec and Britain in the Age of the American Revolution (Montreal and Kingston, 1989), 147-150

${ }^{7}$ Ibid., 128

${ }^{8}$ Bernard Donoughue, British Politics and the American Revolution The Path to War, 1773-75 (London, 1964), 106. Donoughue suggests that the main issues of protest concerning the Opposition in England subsided with the passing of the Bill but remained debatable for the Americans as was declared by the First Continental Congress.
${ }^{9}$ Lawson, Imperial Challenge, 147
${ }^{10}$ Ibid., 126-145

${ }^{11}$ Ibid., 147

${ }^{12}$ Camden to Chatham, 12 Feb. 1775, in Correspondence of William Pitt, Earl of Chatham, vol. 4, eds. W.S. Taylor and J.H. Pringle (London, 1840), 401-2

${ }^{13}$ Gage's official title was "Captain General and Governor in Chief of his Majesty's Province of the Massachusetts Bay." He had been sent by Parliament to put down the disturbances in America after the Boston riots. 
${ }^{14}$ In a letter to Hon. Henry Seymour Conway, for example, Horace Walpole wrote: "The Cabinet have determined on civil war and regiments are going from Ireland and our Wesc Indian Islands. On Thursday the plan of the war is to be laid before both Houses" (Horace Walpole to the Hon. Henry Seymour Conway, 22 January 1775, in Letters of Horace Walpole, vol.9, ed. Mrs. Paget Toynbee [Oxford, 1903], 150).

15 On 9 March 1775, a Bill was put forward by the Ministry restricting trade and commerce to New Jersey, Pennsylvania, Maryland, Virginia, and South Carolina. According to Bernard Donoughue, the Bill "went rapidly through its stages in the Lords and was passed into law on 12 April without an amendment and 'without debate" (British Politics and the American Revolution, 255).

${ }^{16}$ Benjamin Franklin, the colonial agent for the Massachusetts Assembly, had met with Chatham in August of 1774 and on the 27th, 29th, and 31 st of January 1775 in the hopes of having some influence in Chatham's decisions. As it was, Frantlin had had no influence but was content with Chatham's proposals (Ibid., 158).

${ }^{17}$ Lord Frederick North was the first Prime Minister who had acquired the confidence of both the King, George III, and of the House of Commons.

${ }^{18}$ Edmund Burke was a whig polemicist and conservative thinker. As MP since 1766 , he proved to be a leading member of the Rockingham group and he is accredited with writing the Rockingham political ideology in Thoughts on our Present Discontents. Burke first established his reputation through opposition to the duties placed on American trade and later became the colonial representative in London for New York.

19 Note, for example, Lord Rochford to the King, 21 April 1775, in The Correspondence of King George the Third vol. 3, ed. Hon. Sir. John Fortescue (London, 1928), 206. Also see, Horace Walpole to Sir Horace Mann, 7 May 1775, in Letters of Horace Walpole, 190.

20 Parliamentary Register, vol. 1 (London, 1802), 474

${ }^{21}$ The Joumals of the House of Commons, vol. 35 (London, 1803), 376

${ }^{22}$ Journals of the House of Lords, vol. 34 (London, 1775), 458

${ }^{23}$ Horace Walpole, Earl of Oxford, saw himself as the "head of planning and information services" with the Duke of Richmond and orhers in the Opposition. He persisted as a true Whig, commenting frequently in his letrers on the Jacobite tendencies of the Ministry (Duke of Richmond to Horace Walpole, 9 May 1775, Horace Walpole's Correspondence, vol. 41, ed. W.S. Lewis [New Haven, 1937-83], 299, 300).

${ }^{24}$ Walpole to Camden, 12 June 1775, in Ibid., 304

${ }^{25}$ There were approximately 116 Lords counted in attendance on 17 May in the attendance cited in the Journals of the House of Lord, vol. 34, 456.

${ }^{26}$ Correspondence of William Pitt, vol.4, 400-02

${ }^{27}$ Rockingham to Chatham, 9 February 1775 , in Ibid., 400

${ }^{28}$ A. Shortt and A.G. Doughty, eds., Canadian Archives Documents Relating to The Constitutional History of Canada, vol. 1 (Ottawa, 1907), 414

${ }^{29}$ In a letrer to Dartmouth, Carleton wrote: "There have been several Town Meetings since, as they are pleased to stile them, and Meetings of the joint Committees, at which, tis said, they have resolved to write Letters of Thanks to 
the Lord Mayor and Corporation of London, to some of the Merchants in the city, and to Mr. Maseres, for having taken the Province under their Protection, and praying a Continuance of their zealous Endeavours in so good a Cause; . . . Petitions are likewise to be presented to The King, to the Lords, and to the Commons, but of all this I speak doubtfully, as they have taken uncommon Pains to keep their whole Proceedings from my knowledge" (Carleton to Dartmouth, November 1774, in Ibid., 413).

${ }^{30}$ These are only some of the names of those who supported the bills for repeal on 17 and 18 May.

${ }^{31}$ One such occasion was over the General Warrant measure against the "North Briton". Lord Mansfield, or the Honorable William Murray, had supported the illegal action while Camden had ruled against it. Mansfield was also a rival of Chatham as well as a leading figure in the formulation and the passing of the Quebec Bill in 1774. His belief in religious tolerarion subjected him to accusations of Jacobite tendencies by many of his contemporaries. See Foss, Judges of England, 340.

${ }^{32}$ Shelburne to Chatham, 4 April 1774, in Correspondence of William Pitt, vol. 4, 339

${ }^{33}$ See Lord E.G. Firzmaurice, Life of William Earl of Shelburne, vol. 1 (London, 1912), 480.

${ }^{34}$ See the debate in the Lords on the Commons's Ammendments to the Quebec Government Bill, 17 June 1774, in Parliamentary History, vol. 17, 1402.

35 "Proceedings in the Commons on the Bill," 6 June 1774, in Ibid., 1391

${ }^{36}$ See the debate in the House of Lords on the Bill to Repeal the Quebec Government Act on 17 May in Ibid., vol. 18, 657-658.

${ }^{37}$ Ibid., vol. 18, 662-664

${ }^{38}$ William Perty, 2nd Earl of Shelburne, was the MP for Wycombe from 1760 61. Under the Chatham administrations, he was president of the Board of Trade from April - Seprember 1763, and in 1766-68 he was the secretary of state for the Southern Department. Ibid., 671-675

${ }^{39}$ Donoughue, British Politics and the American Revolution, 292

${ }^{40}$ See the debate in the House of Commons on the Bill to Repeal the Quebec Government Act on 18 May in Parliamentary History, vol. 18, 680.

${ }^{41}$ Donoughue, British Politics and the American Revolution, 292

${ }^{42}$ Lawson, Imperial Challenge, 140

${ }^{43}$ See the debate in the Commons on 18 May in Parliamentary History, vol. 18, 681. As yet, I have been unable to secure a record of the voting in the Commons on this question.

${ }^{44}$ Among the more prominent members in favour were Lord Gower, Lord Sandwich, Lord Dartmouth, Lord Mansfield, Lord Lyttelton, Lord Ashburnham, Lord Rochford, viscount C. Townshend, and from the Commons, G. Cooper. Those opposing included the Duke of Richmond, Earl of Coventry, Duke of Gloucester, Eari of Effingham, Earl of Spencer and from the Commons, Howard, Fox, Colonel Barré, Byng, T. Townshend.

${ }^{45}$ Lord Sandys also had voted against the Quebec Bill in 1774 and then did not vote for repeal in 1775 . Unfortunately, there is very little on Sandys which could 
shed some light on his 1775 decision.

${ }^{46}$ Lawson, Imperial Challenge, 132

${ }^{17}$ See the interpretation of the London Evening Post of 16-18 May 1775, cited in Proceedings and Debates of the British Parliament Respecting North America, 17541783, vol. 6, eds., P.D.G. Thomas and R.C. Simmons (New York, 1987), 51. ${ }^{48}$ Fitzmaurice, Life of William Earl of Shelburne, vol. 1, 477

${ }^{49}$ Walpole to Camden, 12 June 1775, in Horace Walpole's Correspondence, vol. 41, 305

${ }^{50}$ Augustus Henry Fitzroy, 3rd Duke of Grafton, was the MP for Bury St Edmunds in 1756. In 1765-66 he was secretary of stare for the Northern Department and nominal head of the 1766 Chatham administration. After Chatham's resignation in 1768, Grafton was the Prime Minister until 1770.

${ }^{51}$ Fitzmaurice, Life of William Earl of Shelburne, vol. 1, 481

${ }^{52}$ Cited in lbid., 481

${ }^{53}$ North stood up in his place to assert, that "if the refractory colonies cannot be reduced to obedience by the present force, he should think it a necessary measure to arm the Roman Catholics of Canada, and to employ them in that service" (debate in the Commons on 18 May in Parliamentary History, vol. 18, 681). ${ }^{51}$ See the published edition of Lord Thomas Lyttelton's speech, The Speech of Lord Lyttelton, (London, 1775), 8. 